\title{
The acceptance of learning management systems and video conferencing technologies: Lessons learned from COVID-19
}

\author{
By Mark Anthony Camilleri ${ }^{12}$ and Adriana Caterina Camilleri ${ }^{3}$
}

Suggested citation: Camilleri, M.A. \& Camilleri, A.C. (2021). The Acceptance of Learning Management Systems and Video Conferencing Technologies: Lessons Learned from COVID-19, Technology, Knowledge and Learning, https://doi.org/10.1007/s10758-021-09561-y

This is a pre-publication version.

\begin{abstract}
During the outbreak of the Coronavirus (COVID-19) pandemic, higher education institutions (HEIs) have shifted from traditional and blended learning approaches to a fully virtual course delivery. This research investigates the students' perceptions on remote learning through asynchronous learning management systems (LMS) and via synchronous video conferencing technologies like Google Meet, Microsoft Teams or Zoom, among others. The data was gathered from a sample of 501 higher education students in a Southern European context. A survey questionnaire included measures that investigated the participants' acceptance of interactive technologies to better understand their utilitarian motivations to use them. The findings suggest that the research participants accessed asynchronous content and interacted with online users, including with their course instructor, in real time. While there are a number of theoretical or opinion papers on the impact of COVID-19 on higher education services, currently, there are still a few empirical papers that shed light on the factors that are having an effect on the students' attitudes and intentions to utilize remote learning technologies. This contribution underlines the importance of maintaining ongoing, interactive engagement with students, and of providing them with appropriate facilitating conditions, to continue improving their learning journey.
\end{abstract}

Keywords: perceived usefulness; perceived interactivity; facilitating conditions; video conferencing; learning management systems, SEM-PLS.

\footnotetext{
1 Department of Corporate Communication, Faculty of Media and Knowledge Sciences, University of Malta, Malta. Email: mark.a.camilleri@um.edu.mt

2 The Business School, University of Edinburgh, Edinburgh, Scotland.

${ }^{3}$ Curriculum Department, Malta College of Arts, Science and Technology, Malta.
} 


\section{Introduction}

An unexpected Coronavirus (COVID-19) pandemic has disrupted the provision of educational services in various contexts around the globe (Rahiem, 2020; Johnson, Veletsianos \& Seaman, 2020; Bolumole, 2020). During the first wave of COVID-19, several educational institutions were suddenly expected to interrupt their face-to-face educational services. They had to adapt to an unprecedented situation. This latest development has resulted in both challenges and opportunities to students and educators (Howley, 2020; Araújo, de Lima, Cidade, Nobre, \& Neto, 2020). Education service providers, including higher education institutions (HEIs) were required to follow their respective governments' preventative social distancing measures and to increase their hygienic practices, to mitigate the spread of the pandemic. Several HEIs articulated contingency plans, disseminated information about the virus, trained their employees to work remotely, and organized virtual sessions with students or course participants.

Course instructors were expected to develop a new modus operandi to deliver their higher education services, in real time (Johnson et al., 2020). During the pandemic, many HEIs migrated from traditional and blended teaching approaches to fully virtual and remote course delivery. However, their shift to online, synchronous classes did not come naturally. COVID-19 has resulted in different problems to course instructors and to their students. In many cases, during the pandemic, educators were compelled to utilize online learning technologies to continue delivering their courses (Fitter, Raghunath, Cha, Sánchez, Takayama \& Matarić, 2020). In the main, educators have embraced the dynamics of remote learning technologies to continue delivering educational services to students, amid peaks and troughs of COVID-19 cases.

Subsequently, policy makers have eased their restrictions when they noticed that there were lower contagion rates in their communities. After a few months of lockdown (or partial lock down) conditions, there were a number of HEIs that were allowed to open their doors. They instructed 
their visitors to wear masks, and to keep socially distant from each other. Most HEIs screened individuals for symptoms as they checked their temperatures and introduced strict hygienic practices like sanitization facilities in different parts of their campuses.

However, after a year and a half, since the outbreak of COVID-19, some academic members of staff were still relying on the use of remote learning technologies like LMSs and video conferencing software to teach their courses (Cesco, Zara, De Toni, Lugli, Betta, Evans \& Orzes, 2021). During the pandemic, they became acquainted with online technologies that facilitated asynchronous learning through text and/or recorded video (Sablić, Mirosavljević \& Škugor, 2020). Moreover, many of them, organized interactive sessions with their students in real time. Very often, they utilized video conferencing platforms including Microsoft Teams, Google Meet, Zoom, D2L, Webex, Adobe Connect, Skype for Business, Big Blue Button and EduMeet, among others. COVID-19 has triggered them to use these remote technologies to engage in two-way communications with their students (Aguilar, 2020).

Although in the past year, there were a number of researchers who have published discursive articles about the impacts of COVID-19 on higher education, for the time being, there are just a few empirical studies on the subject (Bergdahl \& Nouri, 2020; Aguilera-Hermida, 2020; Gonzalez, de la Rubia, Hincz, Comas-Lopez, Subirats, Fort \& Sacha, 2020). This contribution addresses this gap in academia. Specifically, it investigates the facilitating conditions that can foster the students' acceptance and usage of remote learning technologies. It examines the participants' utilitarian motivations to utilize asynchronous learning resources to access course material, and sheds light on their willingness to engage with instructors and/or peers through synchronous, video conferencing software, to continue pursuing their educational programs from home, during an unexpected pandemic situation. 
This study builds on previous theoretical underpinnings on technology adoption (Cheng \& Yuen, 2018; Al-Rahmi, Alias, Othman, Marin \& Tur, 2018; Merhi, 2015; Schoonenboom, 2014; Lin, Zimmer \& Lee, 2013; Chen, Chen \& Kazman, 2007; Ngai, Poon \& Chan, 2007; Davis, 1989). At the same time, it explores the students' perceptions about the interactivity (McMillan \& JangSun Hwang, 2002) of LMS as well as video conferencing software, and sheds light on their HEI's facilitating conditions (Hoi, 2020; Dečman, 2015; Venkatesh, Thong \& Xu, 2012; Venkatesh, Morris, Davis \& Davis, 2003). The rationale of this study is to better understand the research participants' intentions to use remote technologies, to improve their learning journey. To the best of our knowledge, there are no other contributions that have integrated the same measures that have been used in this research. Therefore, this study differentiates itself from the previous literature, and puts forward a research model that is empirically tested.

The article is structured as follows: the following section presents a critical review of the relevant literature. It presents the conceptual framework of this study and formulates the hypotheses for this research. Afterwards, the methodology section describes the method and the measures that were used to capture the data for this quantitative study. Hence, the results section features an analysis and interpretation of the findings. In conclusion, this contribution outlines its theoretical as well as its practical implications. The authors identify their research limitations and outline future research avenues to academia.

\section{Literature review}

\subsection{The development of remote learning}

According to the social constructivist theory, individuals necessitate social interactions (Fridin, 2014; Lambropoulos, Faulkner \& Culwin, 2012; Ainsworth, 2006; Tam, 2000). They develop their abilities by interacting with others. Therefore, online learning environments ought 
to be designed to support and challenge the students' reflective and critical skills, by including interactive learning and collaborative approaches (Rienties \& Toetenel, 2016; Dabbagh \& Kitsantas, 2012; Wang, 2009; Wang, Woo, \& Zhao, 2009). Social constructivism and discoverybased learning techniques emphasize the importance of having students who are actively involved in their learning process. This is in stark contrast with previous educational viewpoints where the responsibility rested with the instructor to teach, and where the learner played a passive, receptive role (Lambropoulos et al., 2012).

In the past decades, the students' active learning has been facilitated with the use of education technologies. Course participants can be separated by distance if they use digital and ubiquitous technologies (Camilleri \& Camilleri, 2017; Moore, Dickson-Deane \& Galyen, 2011; Sánchez \& Hueros, 2010; Motiwalla, 2007). Hence, several pedagogical models are increasingly encouraging educators to blend face-to-face learning methods with technology-mediated instruction (Furió, Juan, Seguí \& Vivó, 2015, Ozkan \& Koseler, 2009). The concept of blended learning suggests that course delivery is carried out in-person and through online media (Thai, De Wever \& Valcke, 2017; Porter, Graham, Spring \& Welch 2014; Gikandi, Morrow \& Davis, 2011). Table 1 features a summary of key theoretical underpinnings that are focused on the provision of online learning and its related paradigms, in the context of higher education. 
Table 1. A non-exhaustive list articles that explored the use of online learning technologies in higher education

\begin{tabular}{|c|c|}
\hline $\begin{array}{ll}\text { Education } & \text { technology } \\
\text { paradigm } & \\
\end{array}$ & Authors \\
\hline Blended Learning & $\begin{array}{l}\text { Thai et al., 2017; Porter et al., 2014; López-Pérez, } \\
\text { Pérez-López \& Rodríguez-Ariza, 2011;Gikandi et al., } \\
\text { 2011; Ozkan \& Koseler, 2009. }\end{array}$ \\
\hline $\begin{array}{lr}\text { Computer-assisted } & \text { learning, } \\
\text { Computer-based } & \text { instruction, } \\
\text { Computer-based } & \text { learning, } \\
\text { Computer mediated learning. }\end{array}$ & $\begin{array}{l}\text { Di Mitri, Schneider, Specht \& Drachsler, 2018; Baturay, } \\
\text { Gökçearslan \& Ke, 2017; Lambić, 2016; Sung, Chang } \\
\text { \& Yang, 2015; Soflano, Connolly \& Hainey, 2015; } \\
\text { Vanderhoven, Raes, Montrieux, Rotsaert \& Schellens, } \\
2015 .\end{array}$ \\
\hline $\begin{array}{l}\text { Distributed learning, distance } \\
\text { learning }\end{array}$ & $\begin{array}{l}\text { Boelens, Voet \& De Wever, 2018; Chen, Wang, } \\
\text { Kinshuk \& Chen, 2014; Viberg \& Grönlund, 2013; } \\
\text { Ocak, 2011; Heilesen, 2010. }\end{array}$ \\
\hline Electronic learning (elearning) & $\begin{array}{l}\text { Jeno, Grytnes \& Vandvik 2017; Gómez-Aguilar, } \\
\text { Hernández-García, García-Peñalvo \& Therón, 2015; } \\
\text { Soflano, Connolly \& Hainey, 2015; Cruz-Benito, } \\
\text { Therón, García-Peñalvo \& Pizarro Lucas, 2015; Agudo- } \\
\text { Peregrina, Iglesias-Pradas, Conde-González, Hernández- } \\
\text { García, 2014; Ng, 2012; Lee, Hsieh \& Hsu, 2011; } \\
\text { Wang, Wu \& Wang, 2009; Motiwalla, 2007. }\end{array}$ \\
\hline Mobile learning (mlearning) & $\begin{array}{l}\text { Crompton \& Burke, 2018; Sánchez-Prieto, Olmos- } \\
\text { Migueláñez \& García-Peñalvo, 2017; Briz-Ponce, } \\
\text { Pereira, Carvalho, Juanes-Méndez \& García-Peñalvo, } \\
\text { 2017; Sung, Chang \& Liu, 2016; Cochrane, 2014; Wu, } \\
\text { Lee, Chang \& Liang, 2013; Valk, Rashid \& Elder, 2010; } \\
\text { Wang, Wu \& Wang, 2009; Motiwalla, 2007. }\end{array}$ \\
\hline $\begin{array}{l}\text { Online learning, online } \\
\text { education }\end{array}$ & $\begin{array}{l}\text { Kurucay \& Inan, 2017; Liyanagunawardena, Adams, } \\
\text { Williams, 2013; Gikandi, Morrow \& Davis, 2011; } \\
\text { Klašnja-Milićević, Vesin, Ivanović \& Budimac, 2011; } \\
\text { Liu, Chen,Sun, Wible \& Kuo, 2010; Sun, Tsai, Finger, } \\
\text { Chen \& Yeh, 2008. }\end{array}$ \\
\hline $\begin{array}{l}\text { Virtual learning, virtual } \\
\text { education }\end{array}$ & $\begin{array}{l}\text { Makransky, Terkildsen \& Mayer, 2019; Rienties \& } \\
\text { Toetenel, 2016; Fowler, 2015; Agudo-Peregrina, } \\
\text { Iglesias-Pradas, Conde-González \& Hernández-García, } \\
\text { 2014; Dalgarno \& Lee, 2010; van Raaij, E.M. \& } \\
\text { Schepers, 2008. }\end{array}$ \\
\hline
\end{tabular}

Today's students are increasingly using online technologies to learn, both in and out of their higher educational institutions (Al-Maroof, Al-Qaysi, \& Salloum, 2021). They are using interactive media to acquire formal and informal skills (Dabbagh \& Kitsantas, 2012), particularly 
when they take part in constructivist activities with their peers and course instructors (Fridin, 2014). This argumentation is consistent with the collaborative learning theory (Lambropoulos et al., 2012; Khalifa \& Kwok, 1999). Students can use digital technologies to access recorded podcasts (Merhi, 2015; Lin et al., 2013), watch videos (Hung, 2016) and interact together through live streaming technologies in real time (Payne, Keith, Schuetzler \& Giboney, 2017). Hence, online education has fostered collaborative learning approaches (Wang, 2009). Computer mediated education enables students to search for solutions, to share online information with their peers, to evaluate each other's ideas, and to monitor one another's work (Lambić, 2016; Sung et al., 2015; Soflano, et al., 2015).

Course participants can use remote technologies, including their personal computers, smart phones and tablets to access their instructors' asynchronous, online resources including course notes, power point presentations, videos clips, case studies, et cetera (Butler, Camilleri, Creed \& Zutshi, 2021; Hung, 2016; Ifenthaler \& Schweinbenz, 2013). Moreover, in this day and age, they are utilizing video conferencing technologies to attend virtual meetings, and to engage in one-toone conversations, or in group discussions and debates with their course instructor and with other students. These virtual programs enable students to engage in synchronous communications with course instructors, to ask questions, and receive feedback, in real time.

Many educators are supporting group interactions in collaborative learning contexts (Kurucay \& Inan, 2017). Synchronous technologies allow them to control and monitor their students' engagement, and to keep a track record of their interactions during virtual sessions (Camilleri, 2021a). As a result, that can be in a better position to implement student-centered strategies and tactics, to improve learning outcomes. 


\subsection{The conceptual framework and formulation of the research hypotheses}

There are various contributions in academia that have explored the use of educational technologies in various contexts (Mcstay, 2020; Rakes, Ronau, Bush, Driskell, Niess, \& Pugalee, 2020; Dumpit \& Fernandez, 2017; Anshari, Almunawar, Shahrill, Wicaksono \& Huda, 2017; Lee \& Lee, 2014; Billinghurst \& Duenser, 2012; Selwyn, 2010). Several studies relied on the theory of reasoned action (TRA) (Althunibat, 2015), the theory of planned behavior (TPB) (Camilleri \& Camilleri, 2020; Rana, Slade, Kitching \& Dwivedi, 2019; Ahmed \& Ward, 2016; Park, Nam \& Cha, 2012; Cheon, Lee, Crooks \& Song, 2012; Moss, O'Connor \& White, 2010; Shih, 2008), the unified theory of acceptance and use of technology (UTAUT) (Hoi, 2020; Dečman, 2015; Althunibat, 2015; Lin et al., 2013) and the theory of acceptance model (TAM) (Camilleri \& Camilleri, 2019; Cheng \& Yuen, 2018; Al-Rahmi et al., 2018; Merhi, 2015; Schoonenboom, 2014; Lin et al., 2013; Sánchez-Franco, 2010; Sánchez-Franco, Martínez-López, Martín-Velicia, 2009; Ngai et al., 2007; Davis, 1989), among others, to explore the acceptance and use of a wide array of education technologies.

Davis' (1989) TAM was adapted to investigate the students' acceptance of WebCT (Sánchez-Franco, 2010; Ngai et al., 2007), web-based electronic learning (Sánchez-Franco et al., 2009); learning management systems (Cheng \& Yuen, 2018; Schoonenboom, 2014); social media (Al-Rahmi et al., 2018), podcasts (Merhi, 2015; Lin et al., 2013) in higher education. His model consists of five items, including the perceived ease of use, perceived usefulness, attitudes toward the technology, intentions to use technology and actual behaviors (Camilleri \& Camilleri, 2017; Davis, 1989).

Many researchers, including Davis (1989) indicated that the participants' perceived usefulness has a positive and significant effect on their attitudes and on their intentions to use technologies (Cheng \& Yuen, 2018; Al-Rahmi et al., 2018; Merhi, 2015; Schoonenboom, 2014). Al-Rahmi et al. (2018) indicated that the students' perceptions about the usefulness of social media 
have led them to engage in active collaborative learning. They went on to suggest that these technologies facilitated group discussions. Other studies confirmed that it is very likely that students would be willing to use certain learning technologies like podcasts if they perceived their utility to enhance their knowledge (Merhi, 2015). Various studies have yielded mixed findings on the use of learning technologies in the context of higher education. For instance, Cheng and Yuen (2018) reported that the individuals' perceived usefulness and attitudes toward these educational technologies diminished over time.

Various researchers found that the individuals' attitudes toward the usage of technology had a significant influence on their intentions and their actions (Cheng \& Yuen 2018; Teo \& Zhou, 2014; Tao et al., 2009; Sánchez-Franco et al., 2009). However, other researchers reported that the individuals' attitudes towards technology did not always correlate with their intentions to use them. For instance, Cheon et al. (2012) reported that there were direct effects between the individuals' attitudes toward the usage of technology on their behavioral intentions. Other researchers including Nistor (2013) indicated that the students' attitudes did not have a significant effect on their participation in online courses. Perhaps, the reason for this is that course participants are expected to use certain technologies as a requirement to complete their educational program, whether they like it or not. In any case, this research is consistent with the TAM model. This study hypothesizes that:

H1: The individuals' perceived usefulness of remote learning technologies will have a positive and significant effect on their attitudes toward them.

H2: The individuals' perceived usefulness of remote learning technologies will have a positive and significant effect on their intentions to use them.

H2a: The individuals' attitudes toward remote learning technologies mediates this relationship. 
H3: The individuals' attitudes toward remote learning technologies will have a positive and significant effect on their intentions to use them.

Course instructors can utilize remote learning technologies to upload their digital learning resources, including presentations, notes, quizzes, videos and assessments for their students' guidance. Hence, students can access interactive resources through different digital media including mobile technologies, like laptops, smartphones and tablets, at their own convenience, from the comfort of their home. These remote learning technologies offer asynchronous as well as synchronous learning opportunities. Their interactive capabilities allow students to remain active in their learning experience, as they involve multiple processes, functions and perceptions.

There are several researchers who have attempted to define interactivity. Perceived interactivity refers to the extent to which individuals perceive that those technologies would allow them to feel in control when they communicate with others (Chattaraman, Kwon, Gilbert \& Ross, 2019; Liu, 2003). Chen et al. (2007) argued that interactivity is related to media richness. They contended that different media vary in their ability to improve communication, and thus can be characterized as high or low, in terms of "richness", depending on their ability to facilitate shared meanings. The efficacy of interactive communications is based on the immediacy of feedback, multiple cues, language variety and personal focus (Chen et al., 2007).

Thorson and Rodgers (2006) maintained that the concepts of interactivity can be categorized into human-to-human, human-to-document, and human-to-system interactions. Previously, McMillan and Jang-Sun Hwang (2002) held that there are three overlapping elements that are present in the interactivity literature: direction of communication, user control, and time. They went on to suggest that the direction of communication encompasses the concepts of responsiveness and exchange. Whilst user control and the concept of time embrace issues such as the importance of timely feedback (i.e., the time required for information retrieval). 
Individuals can utilize asynchronous learning resources to read and share documents, listen to podcasts and to watch online videos. They can also use synchronous technologies like video conferencing facilities to engage in two-way communications with their instructor(s) and with their peers, in real time. Many academic researchers reported that online users perceived that the interactivity of the Internet had a positive effect on their attitudes towards websites $(\mathrm{Wu}, 2005$; Fiore \& Jin, 2003).

Chen, Chen and Kazman, (2007) reported that there were significant correlations between the perceived interactivity of technology and their perceived usefulness. Subsequently, Park (2015) indicated that their research participants required high levels of teacher or moderator intervention during online learning. The author posited that the learner-teacher interaction was one of the most influential characteristics of online learning as it supported reflective learning processes. He confirmed that the students' perceptions of online collaborative learning were an important predictor for their active participation in class. Moreover, Park (2015) reported that the course instructors' (interactive) responsiveness was highly valued by their students. In other words, the students' interaction with other online users was having a positive effect on their perceptions about the usefulness of interactive technologies (to improve their learning outcomes). This argumentation leads to the following hypotheses:

H4: The individuals' perceptions about the interactivity of remote learning technologies will have a positive and significant effect on their perceived usefulness.

Product factors such as technological complexity (Teo, 2009), user factors like computer self-efficacy (Ifenthaler, 2012; Hartshorne \& Ajjan, 2009), and environmental factors, including technical or organizational support (Gangwar, Date \& Ramaswamy, 2015) can also be integrated in empirical models when investigating the utilitarian usage of education technologies. Venkatesh 
et al. (2003; 2012) posited that facilitating conditions including tangible elements like infrastructures, equipment and technology, as well as intangible aspects like the provision of training, development and support for the users of technology, can influence the individuals' intentions to utilize certain technologies. Ngai et al. (2007) reported that facilitating conditions like technical support has a positive effect on the students' perceptions and attitudes towards using WebCT. Similarly, Teo (2009) as well as Lin et al. (2013) also argued that appropriate infrastructures and the delivery of adequate training and support would probably entice the individuals' intentions to engage with educational technologies. This argumentation leads to the following hypotheses:

H5: Facilitating conditions will have a positive and significant effect on the individuals' perceptions about the interactivity of remote learning technologies.

H6: Facilitating conditions will have a positive and significant effect on the individuals' perceived usefulness of remote learning technologies.

H7: Facilitating conditions will have a positive and significant effect on the individuals' attitudes toward remote learning technologies.

Figure 1. illustrates the research model of this empirical investigation as it describes the hypothesized relationships. 


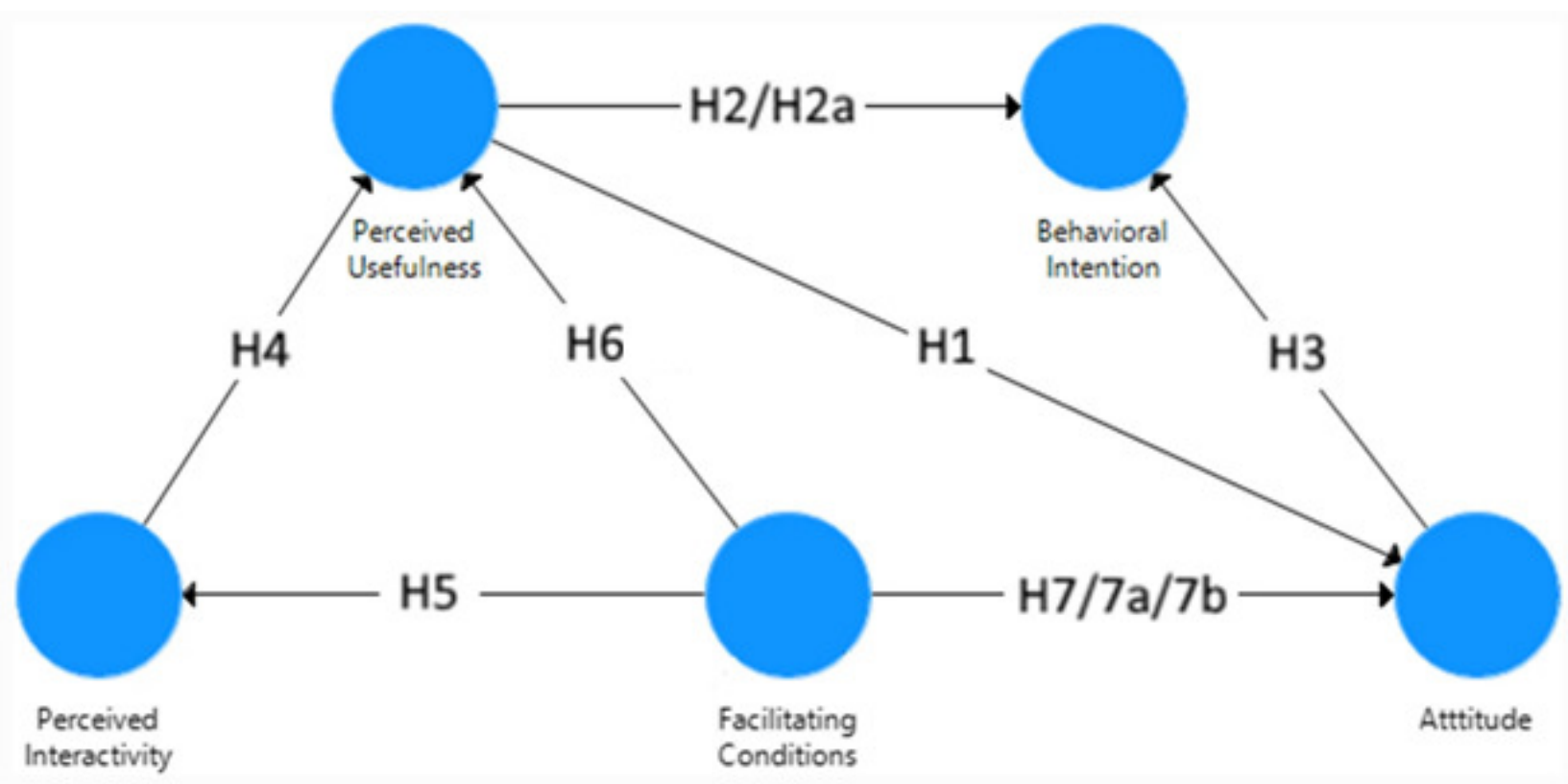

Figure 1. A research model that investigates the individuals' intentions to use remote learning technologies

\section{Methodology}

\subsection{The questionnaire's measures}

The questionnaire's items were adapted from valid and reliable academic sources. They were drawn from key theoretical underpinnings, including from TAM (Cheng \& Yuen, 2018; Lin et al., 2013; Davis, 1989), TPB (Park et al., 2012; Ajzen, 1991) and UTAUT (Hoi, 2020; Dečman, 2015; Venkatesh et al., 2003; 2012). This research integrated the perceived usefulness - PU (4 items), attitudes - ATT (2 items), facilitating conditions - FC ( 2 items) and behavioral intentions -BI (2 items) with a construct relating to perceived interactivity - PI (3 items) (Chattaraman et al., 2019; McMillan \& Jang-Sun Hwang, 2002). The measures that were used in this research are illustrated in Table 2. 
Table 2. The survey questionnaire's constructs and their corresponding items

\begin{tabular}{|c|c|c|}
\hline \multicolumn{2}{|l|}{ Construct } & Items \\
\hline \multirow{4}{*}{$\begin{array}{l}\text { Perceived } \\
\text { Usefulness } \\
\text { (Cheng \& Yuen, } \\
\text { 2018; Lin et al., } \\
\text { 2013; Ngai et al., } \\
\text { 2007). }\end{array}$} & PU1 & Remote learning is useful. \\
\hline & PU2 & Remote learning increases my chances of learning. \\
\hline & PU3 & The remote learning technologies help me learn things. \\
\hline & PU4 & Remote learning improves my learning outcomes. \\
\hline \multirow{3}{*}{$\begin{array}{l}\text { Perceived } \\
\text { Interactivity } \\
\text { (Chattaraman et } \\
\text { al., 2019; Chen et } \\
\text { al., 2007; } \\
\text { McMillan \& Jang- } \\
\text { Sun Hwang, 2002). }\end{array}$} & PI1 & $\begin{array}{l}\text { I would use the remote learning technologies' multimedia } \\
\text { features. }\end{array}$ \\
\hline & PI2 & $\begin{array}{l}\text { I would click through the remote learning technologies' } \\
\text { online resources. }\end{array}$ \\
\hline & PI3 & $\begin{array}{l}\text { I would participate in online discussions with the course } \\
\text { instructor and my peers. }\end{array}$ \\
\hline \multirow{3}{*}{$\begin{array}{l}\text { Facilitating } \\
\text { Conditions } \\
\text { (Hoi, 2020; } \\
\text { Dečman, 2015; } \\
\text { Venkatesh et al. } \\
\text { 2003; 2012). }\end{array}$} & $\mathrm{FC} 1$ & $\begin{array}{l}\text { I have the resources necessary to use remote learning } \\
\text { technologies. }\end{array}$ \\
\hline & FC2 & $\begin{array}{l}\text { I have the knowledge necessary to use remote learning } \\
\text { technologies. }\end{array}$ \\
\hline & FC3 & $\begin{array}{l}\text { I can get help from others when I have difficulties using } \\
\text { remote learning technologies. }\end{array}$ \\
\hline \multirow{2}{*}{$\begin{array}{l}\text { Attitude } \\
\text { (Rana et al., 2019; } \\
\text { Ahmed \& Ward, } \\
\text { 2016; Shih, 2008). }\end{array}$} & ATT1 & $\begin{array}{l}\text { The quality of education that is provided through remote } \\
\text { learning technologies is good. }\end{array}$ \\
\hline & ATT2 & I like using remote learning technologies. \\
\hline \multirow{2}{*}{$\begin{array}{l}\text { Behavioral } \\
\text { Intention } \\
\text { (Ahmed \& Ward, } \\
\text { 2016; Cheon et al., } \\
\text { 2012). }\end{array}$} & BI1 & $\begin{array}{l}\text { It is very likely that I shall continue using remote learning } \\
\text { technologies in the future. }\end{array}$ \\
\hline & $\mathrm{BI} 2$ & $\begin{array}{l}\text { Probably, I will use remote learning technologies in my daily } \\
\text { life. }\end{array}$ \\
\hline
\end{tabular}

The survey instrument was pilot tested with a small group of experienced colleagues to identify any possible weaknesses. It considered the effects of the research participants' response styles, the proximity of related and unrelated constructs and the items' wording, in order to reduce the plausibility of common method bias (MacKenzie \& Podsakoff, 2012). The questionnaire consisted of 16 multiple choice questions including three demographic ones, that were placed in the latter part of the survey. The participants disclosed their demographic information about their age, gender and experience with remote learning technologies. They could complete the 
questionnaire in less than five minutes. The responses were coded on a five-point Likert scale, ranging from 1 (strongly disagree) to 5 (strongly agree) with 3 signaling a neutral position.

\subsection{The sample}

The respondents were registered students in a Southern European university. A cover letter comprising a link to this study's survey questionnaire was disseminated via email to more than 11,000 students. The recipients of this email were following full time, part time and distance learning courses. The respondents were informed about the objectives of this empirical investigation and were provided with some guidelines on how to complete the questionnaire.

After a month, there were 508 responses to the survey. The returned questionnaires were carefully examined and crosschecked to determine if they had incomplete responses. There were seven questionnaires that were not included in the analysis as they had missing values. Hence, the research sample of this study consisted of 501 valid responses. The frequency table reported that there were three hundred fourteen females $(n=314)$ and one hundred eighty-seven males $(n=187)$ who took part in this study. The respondents were classified into five age groups $(18-23 ; 24-29$; 30-35; 36-41 and over 42 years of age). Most of the research participants were between 18 and 23 years of age $(n=326)$, followed by those between 24 and 29 years of age $(n=121)$. The majority of respondents $(n=474)$ revealed that they have been using remote technologies, including asynchronous LMS as well as video conferencing technologies, during COVID-19.

\section{Results}

\subsection{The descriptive statistics}

The researcher examined the mean (M) scores and the standard deviations (SD) through SEM-PLS 3.3.3 statistical software. Generally, the respondents suggested that the respondents 
agreed with the survey's statements as there were high mean scores above the midpoint (3). The highest mean scores were reported for PU3 $(\mathrm{M}=4.745)$, FC1 $(\mathrm{M}=4.717)$ and FC3 $(\mathrm{M}=4.635)$. Whilst PU3 reported the lowest mean score $(M=3.886)$. There were small variances in the participants' responses. The values of the standard deviation (SD) varied from 0.318 (for PU2) to 0.568 (for PU1), as featured in Table 3. 
Table 3. An assessment of the composite reliability, convergent validity and discriminant validity

\begin{tabular}{|c|c|c|c|c|c|c|c|c|c|c|c|c|}
\hline Construct & & Items & $\begin{array}{c}\text { Outer } \\
\text { Loadings }\end{array}$ & Mean & SD & CR & AVE & 1 & 2 & 3 & 4 & 5 \\
\hline \multirow{2}{*}{1} & \multirow{2}{*}{ Attitude } & ATT1 & 0.925 & 4.176 & 0.495 & \multirow{2}{*}{0.935} & \multirow{2}{*}{0.878} & \multirow{2}{*}{0.937} & \multirow{2}{*}{0.588} & \multirow{2}{*}{0.548} & \multirow{2}{*}{0.482} & \multirow{2}{*}{0.614} \\
\hline & & ATT2 & 0.949 & 4.138 & 0.468 & & & & & & & \\
\hline \multirow{2}{*}{2} & \multirow{2}{*}{ Behavioral Intentions } & BI1 & 0.649 & 4.246 & 0.430 & \multirow{2}{*}{0.720} & \multirow{2}{*}{0.578} & \multirow{2}{*}{0.318} & \multirow{2}{*}{0.760} & \multirow{2}{*}{0.486} & \multirow{2}{*}{0.614} & \multirow{2}{*}{0.593} \\
\hline & & $\mathrm{BI} 2$ & 0.924 & 4.377 & 0.485 & & & & & & & \\
\hline \multirow{2}{*}{3} & \multirow{2}{*}{ Facilitating Conditions } & FC1 & 0.917 & 4.717 & 0.451 & \multirow{2}{*}{0.847} & \multirow{2}{*}{0.736} & \multirow{2}{*}{0.422} & \multirow{2}{*}{0.214} & \multirow{2}{*}{0.858} & \multirow{2}{*}{0.849} & \multirow{2}{*}{0.811} \\
\hline & & FC2 & 0.795 & 4.579 & 0.558 & & & & & & & \\
\hline \multirow{3}{*}{4} & \multirow{3}{*}{ Perceived Interactivity } & PI1 & 0.778 & 4.301 & 0.535 & \multirow{3}{*}{0.825} & \multirow{3}{*}{0.614} & \multirow{3}{*}{0.390} & \multirow{3}{*}{0.227} & \multirow{3}{*}{0.613} & \multirow{3}{*}{0.784} & \multirow{3}{*}{0.776} \\
\hline & & PI2 & 0.671 & 4.453 & 0.498 & & & & & & & \\
\hline & & PI3 & 0.887 & 3.896 & 0.411 & & & & & & & \\
\hline & & PU1 & 0.857 & 4.577 & 0.568 & & & & & & & \\
\hline 5 & Domorived I tof & PU2 & 0.826 & 3.886 & 0.318 & 0000 & 0607 & 0522 & 0200 & 0641 & 0.71 & 0020 \\
\hline 5 & Perceıved Usefulness & PU3 & 0.866 & 4.745 & 0.436 & 0.898 & 0.681 & 0.523 & 0.292 & 0.641 & $0.6 / 1$ & 0.829 \\
\hline & & PU4 & 0.763 & 4.168 & 0.540 & & & & & & & \\
\hline
\end{tabular}

Note: The square root of AVE for each construct was greater than the correlation involving the other constructs in the same column, as per Fornell-Larcker criterion. The shaded areas feature the results from the Heterotrait Monotrait Ratio (HTMT). The correlations re-confirmed the presence of discriminant validity across most of the constructs, where the values were lower than the recommended threshold of 0.9 (Henseler, Ringle \& Sarstedt, 


\subsection{Confirmatory composite analysis}

This study relied on the SEM-PLS confirmatory composite analysis (CCA) to assess this research model (Hair, Howard, Nitzl, 2020; Ringle, Wende \& Becker, 2014). The PLS algorithm shed light on the results from the outer loadings, composite reliability, average variance extracted (AVE) and discriminant validity values. Table 3 indicates that the composite reliability values were between 0.720 and 0.935 . It also confirmed that the values for AVE were higher than 0.5. There was evidence of discriminant validity as the square root value of AVE was greater than the correlation values among the latent variables (Fornell \& Larcker, 1981). This study also examined heterotrait-monotrait (HTMT) ratio of the correlations, thus it re-confirmed the presence of discriminant validity as HTMT values were lower than 0.9 threshold (Henseler, Ringle \& Sarstedt, 2015).

\subsection{Structural model assessment and interpretation of the findings}

The assessment criteria involved an examination of the collinearity among the constructs. The results indicated that there were no collinearity issues as the variance inflation factors (VIFs) have exceeded the recommended threshold of 3.3 (Hair et al., 2020). A bootstrapping procedure was used to explore the statistical significance and relevance of this research model's path coefficients. The significance of the hypothesized path coefficients in the inner model were evaluated by using a two-tailed $t$-test. Table 4 reveals the results of the hypotheses of this study. It sheds light on the direct effects among the constructs. It features the standardized beta coefficients (original sample), the confidence intervals, $t$-values and the significance values $(p)$. Table 5 summarizes the results of the mediation analysis. It presents a summary of the total effects of this research model and clearly identifies the direct as well as the indirect effects among the constructs. 
Table 4. Testing of the Hypotheses

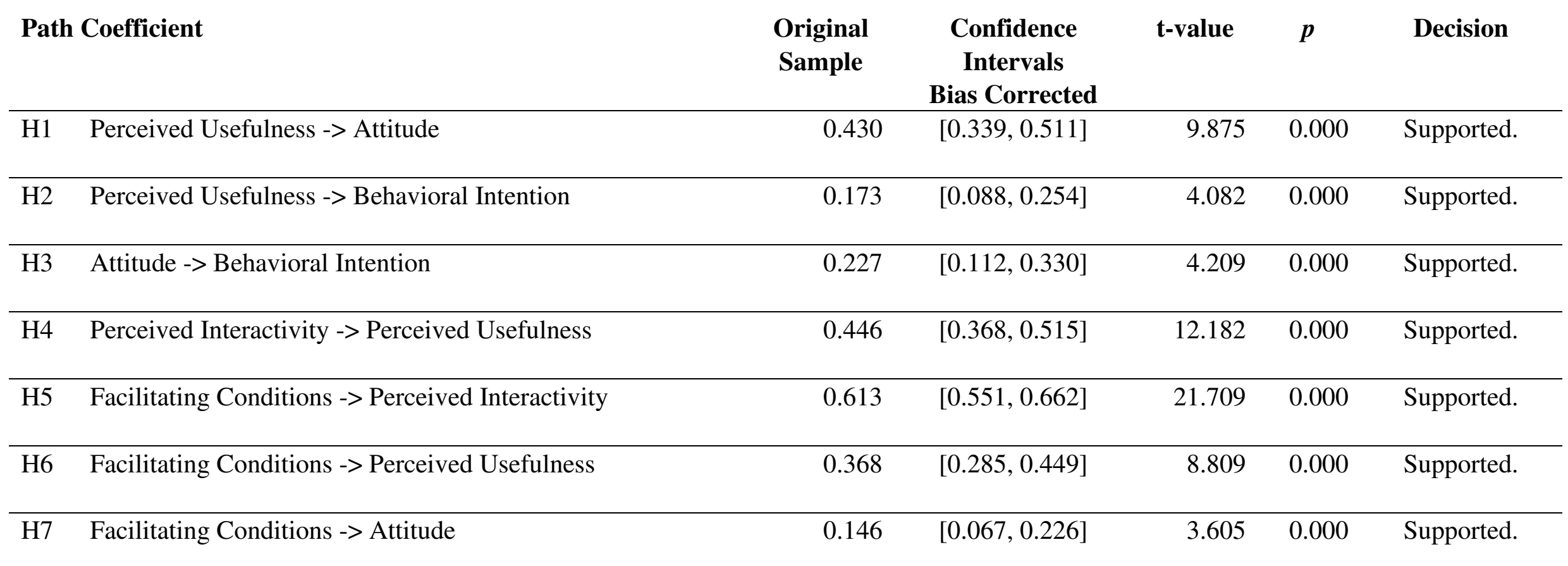

Note: Critical values are $\mathrm{t}<1.96 ; p<0.001$ for $\mathrm{H} 1-\mathrm{H} 7$. 
Table 5. The mediation analysis

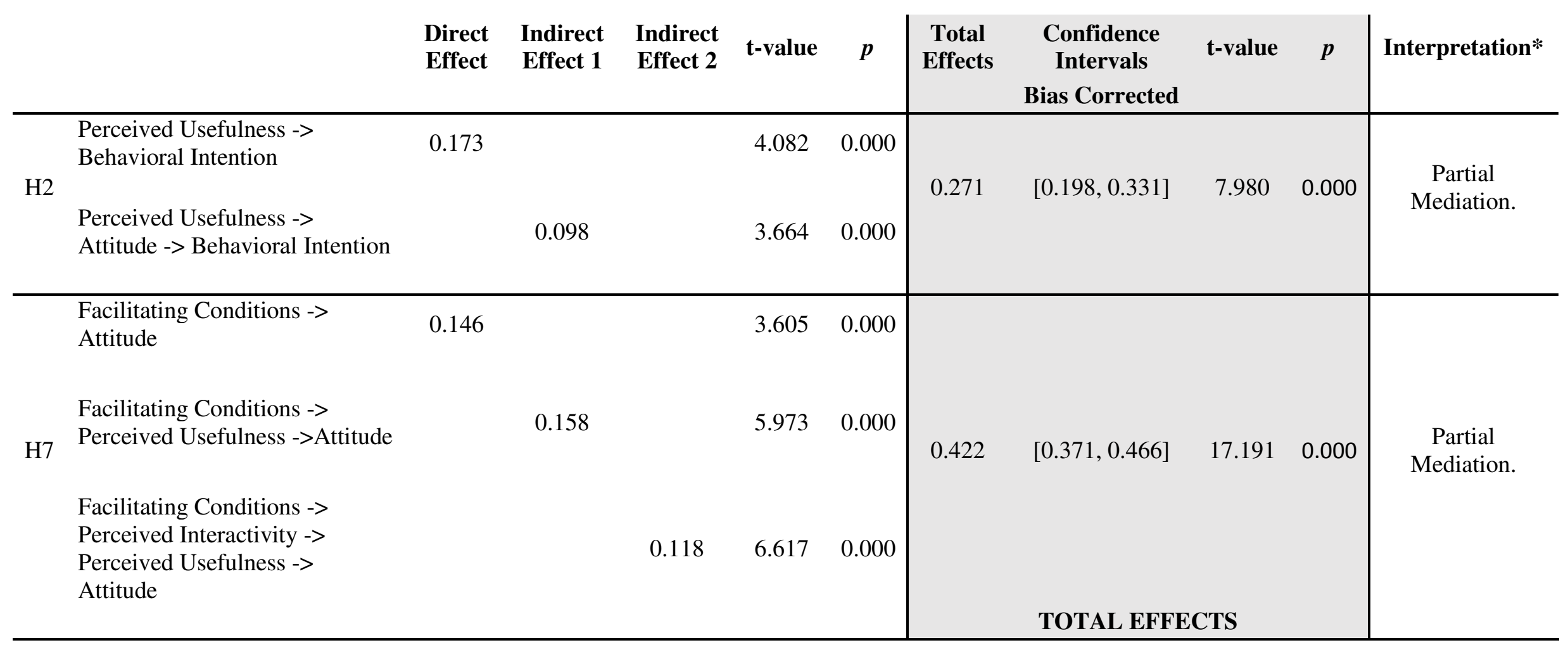


Figure 2 the depicts the explanatory power of this research model. It sheds light on the total effects and on the coefficient of determination (adj. R squared) values of the constructs.

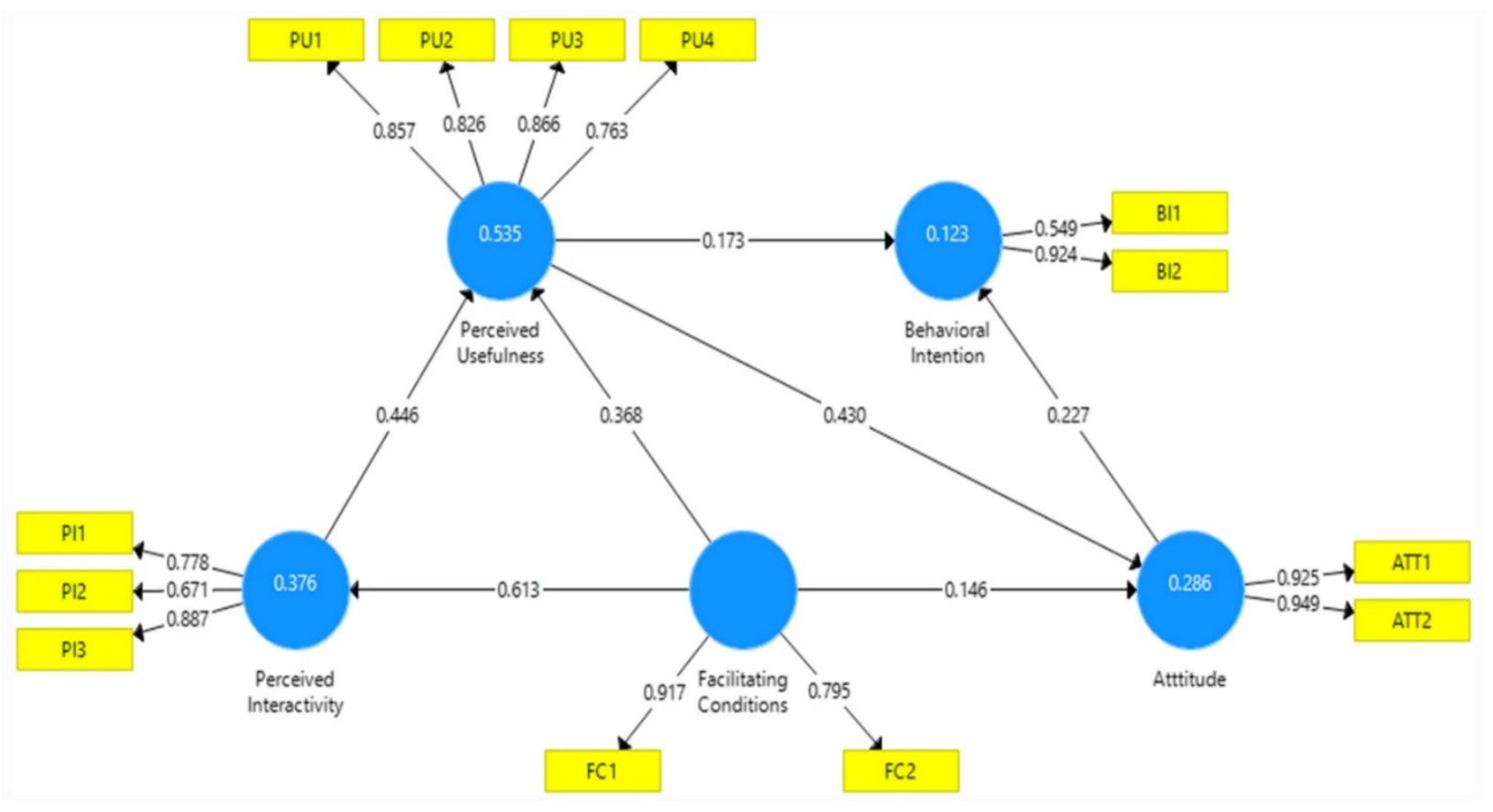

Figure 2. A graphical illustration of the results

This study reported that PU was the precursor of ATT $(\beta=0.430, t=9.875, p<0.001)$ and of $\mathrm{BI}(\beta=0.173, \mathrm{t}=4.082, p<0.001)$. These finding suggest the students' perceived usefulness of the remote learning technologies strongly predicted their attitude towards them and were also having a significant effect on their intentions to use them. Moreover, the results evidenced a similar effect between ATT and BI (where $\beta=0.227, \mathrm{t}=4.209, p<0.001$ ). There were very significant effects between PI-PU $(\beta=0.446, \mathrm{t}=12.182, p<0.001)$ and between FC-PI $(\beta=0.613, \mathrm{t}=21.709$, $\mathrm{p}<0.001)$. There were other highly significant links between FC-PU $(\beta=0.368, \mathrm{t}=8.809, \mathrm{p}<$ $0.001)$ and FC-ATT $(\beta=0.146, \mathrm{t}=3.605, p<0.001)$.

PU had the highest level of explanatory power in this research model (where Adj. $\mathrm{R}^{2}=$ 0.535). There was a moderate coefficient of determination for PI (Adj. $\mathrm{R}^{2}=0.376$ ), and for ATT 
(adj. $\mathrm{R}^{2}=0.286$ ). Whilst adj. $\mathrm{R}^{2}$ for $\mathrm{BI}$ was the lowest at 0.123 . The mediation analyses indicated that the relationship between FC and ATT was partially mediated by PU $(\beta=0.158, \mathrm{t}=5.973, p$ $<0.001)$. In addition, both PU as well as PI were mediating FC-ATT $(\beta=0.118, \mathrm{t}=6.617, p<$ 0.001). Moreover, ATT was partially mediating PU-BI link $(\beta=0.098, \mathrm{t}=3.664, p<0.001)$.

\section{Discussion and conclusions}

\subsection{Theoretical implications}

A critical review of the relevant literature reported that university students were already using asynchronous technologies, in different contexts, before the outbreak of COVID-19 (Butler et al., 2021; Sánchez-Prieto et al., 2017; Hung, 2016; Liu et al., 2010; Sánchez \& Hueros, 2010). Many authors held that online technologies were improving the students' experiences (Crompton \& Burke, 2018; Kurucay \& Inan, 2017; Sánchez-Prieto et al., 2016). Before the outbreak of COVID-19, many practitioners blended traditional learning methodologies with digital and mobile applications to improve learning outcomes (Al-Maroof et al., 2021; Boelens et al., 2018; Furió et al., 2015). Course instructors can design and develop online learning environments to support their students with asynchronous resources (Wang et al., 2009). They may allow them to engage in

collaborative learning activities through virtual environments (Rienties \& Toetenel, 2016; Dabbagh \& Kitsantas, 2012). These contemporary approaches are synonymous with the social constructivist theory (Fridin, 2014; Lambropoulos et al., 2012) and with discovery-based learning (Ifenthaler, 2012; Lambropoulos et al., 2012).

This contribution investigated the students' perceived usefulness, perceived interactivity, attitudes toward use, facilitating conditions and behavioral intentions to utilize remote technologies. It posited that higher education students perceived the usefulness of remote learning technologies including LMS and video conferencing programs during COVID-19. The findings clearly indicated that they valued their interactive attributes. These factors have led them to 
embrace these programs during their learning journey. This study also confirmed that the universities' facilitating conditions had a significant effect on their perceptions about the interactivity of these online learning resources and on their attitudes towards these technologies. This finding is consistent with previous research that reported that facilitating conditions is positively related to the students' intentions to continue using digital and mobile learning resources (Gangwar et al., 2015; Teo, 2009).

This study has differentiated itself from previous contributions as it integrated facilitating conditions (Hoi, 2020; Dečman, 2015; Venkatesh et al. 2003; 2012) and perceived interactivity (Chattaraman et al., 2019; Chen et al., 2007; McMillan \& Jang-Sun Hwang, 2002) with perceived usefulness (of technology) and attitudes (toward the use of technology) to better understand the students' intentions to utilize remote learning technologies to improve their learning journey (Cheng \& Yuen, 2018; Al-Rahmi et al., 2018; Merhi, 2015; Schoonenboom, 2014; Lin et al., 2013; Ngai et al., 2007; Davis, 1989) during an unexpected pandemic situation.

A recent bibliographic analysis revealed that there are a number of theoretical papers that have been published in the last eighteen months on this hot topic (Cesco et al., 2021; Fitter et al., 2020; Howley, 2020; Rahiem, 2020). Yet, to date, there are just a few rigorous studies, that examined the utilization of synchronous video conferencing technologies, in addition to conventional, asynchronous content, like LMS, in the context of higher education (AguileraHermida, 2020; Gonzalez et al., 2020).

The findings from this research shed light on the utilitarian factors that were influencing the students' engagement with interactive learning resources. According to the descriptive statistics, the students felt that remote technologies were useful to achieve their learning outcomes. They indicated that they were provided with appropriate facilitating conditions that enabled them to migrate to a fully virtual learning environment from face-to-face or blended learning approaches. During the pandemic's lockdown or partial lockdown conditions, and even when the 
preventative measures were eased, many students were still using remote learning technologies to access online educational resources. They also kept using video conferencing technologies to attend to virtual classes, and to engage with their course instructor(s) and with their peers, in real time.

The confirmatory composite analysis reported that there were positive and highly significant effects that predicted the students' intentions to use remote learning technologies. Evidently, educators have provided them with the necessary resources, knowledge and technical support to avail themselves of remote learning technologies. The respondents indicated that they accessed their course instructors' online resources and regularly interacted with them through live conferencing facilities. The findings from SEM-PLS confirmed that the perceived usefulness and perceived interactivity with online technologies had a positive effect on their attitudes toward remote learning. This research implies that the students were confident with the utilization of interactive technologies to continue their educational programs. In fact, this research model proved that they were likely to use synchronous and asynchronous learning technologies in the foreseeable future, in a post COVID-19 context.

\subsection{Implications of study for educators and policy makers}

The COVID-19 pandemic and its preventative measures urged HEIs and other educational institutions to embrace video conferencing technologies to continue delivering student-centered education. This research suggests that educators ought to monitor their students' engagement during their virtual sessions. It revealed that the students' perceived interactivity as well as their higher education institutions' facilitating conditions were having an effect on their perceptions about the usefulness of remote learning, on their attitudes as well as on their intentions to use them. These digital technologies were supporting the research participants in their learning journeys, whether they were at home or on campus. The students themselves perceived the usefulness of 
asynchronous LMS as well as of synchronous communications, including video conferencing software like Zoom or Microsoft Teams, among others.

These virtual technologies were already utilized in various contexts, before the outbreak of COVID-19. However, they turned out to be important learning resources in the realms of education. Course instructors are expected to support their students, by developing attractive digital learning resources (e.g. interactive presentations, online articles and recorded video clips) in appropriate formats that can be accessed with ease, through different media, including mobile technologies (Sablić et al., 2020). In this day and age, they can also use video conferencing technologies to interact with course participants in real time. When engaging with online resources, instructors should consider their students' facilitating conditions, particularly if they are including high-res images, interactive media, including podcasts, videos, etc., in their LMSs. Their asynchronous content should be as clear and focused as possible, with links to relevant sources, including notes, case studies, quizzes, rubrics and formative assessments, among others.

COVID-19 has taught us that the individuals' engagement with LMS and video conferencing software necessitate high-quality wireless networks. There may be situations where students as well as their instructors may require online technical support, whether they are working from home of from university premises. Educational institutions including HEIs ought to regularly evaluate their students' experiences with remote teaching in order to identify any issues that are affecting their academic performance (Camilleri, 2021b). HEI leaders are not always in a position to evaluate the quality and standards of their instructors' online learning methods and to determine with absolute certainty whether their students have achieved their learning outcomes. During remote course delivery, students may not always have access to appropriate interactive technologies, learning materials or to adequate productive environments (Bao, 2020). There can be instances where course instructors and students could require facilitating conditions like 
technical support or training and development to enhance their competences and capabilities with the use of remote technologies.

\subsection{Research limitations and future research directions}

This study investigated the students' perceptions and attitudes on the use of asynchronous as well as synchronous, learning technologies in higher education. It identified the factors and the facilitating conditions that are having an effect on their intentions to use LMS and video conferencing software. However, the students' stance toward the use of education technologies can change over time. Indeed, there is scope for further research that investigates the impact of remote teaching through digital and mobile learning technologies on the students' learning journeys. The transition to a fully virtual, online teaching and learning environment through remote technologies may (or may not) be effective for the delivery of some courses. There are a few subjects that cannot be taught remotely.

Prospective research can use different methodologies, sampling frames and analytical techniques to shed more light about the students' experiences and satisfaction levels with remote learning. Future studies can explore the students' perceptions about their educational institution's service quality and performance, particularly if they are relying on remote course delivery. Moreover, long-term longitudinal studies could possibly provide a better understanding of the students' engagement with synchronous and asynchronous technologies.

\subsection{Conclusion}

COVID-19 has had an impact on the delivery of higher educational services. It has disrupted the education of millions of students in different contexts (Bergdahl \& Nouri, 2020). However, on a positive note, it has opened a window of opportunity for higher education stakeholders. This unexpected pandemic and its preventative measures have triggered HEIs (and 
their course instructors) to use new teaching methodologies involving synchronous, interactive communications to continue delivering their curricula and educational programs. Their sudden and unprecedented closure has led them to experiment with virtual education technologies and to engage with their students in real time, through video conferencing software. Arguably, the integration of education technologies in higher education may be accelerated in the foreseeable future as the utilization of remote communications may increasingly become the norm, in a post COVID-19 era. Therefore, HEIs ought to invest in online learning infrastructures, resources and facilitating conditions, for the benefit of their students and faculty employees.

\section{Declarations}

- Availability of data and materials: The datasets used and/or analyzed during the current study are available from the corresponding author on request.

- Funding: The authors availed themselves of their institutions' academic work resources funds.

- Acknowledgements: The authors express their gratitude to the respondents who participated in this study.

\section{References}

Agudo-Peregrina, Á. F., Iglesias-Pradas, S., Conde-González, M. Á., \& Hernández-García, Á. (2014). Can we predict success from log data in VLEs? Classification of interactions for learning analytics and their relation with performance in VLE-supported F2F and online learning. Computers in Human Behavior, 31, 542-550.

Aguilar, S. J. (2020). Guidelines and tools for promoting digital equity. Information and Learning Sciences, 121(5/6), 285-299.

Aguilera-Hermida, A. P. (2020). College students' use and acceptance of emergency online learning due to Covid-19. International Journal of Educational Research Open, 1 https://www.sciencedirect.com/science/article/pii/S266637402030011X

Ahmed, E., \& Ward, R. (2016). Analysis of factors influencing acceptance of personal, academic and professional development e-portfolios. Computers in Human Behavior, 63, 152-161. 
Ainsworth, S. (2006). DeFT: A conceptual framework for considering learning with multiple representations. Learning and Instruction, 16(3), 183-198.

Al-Maroof, R., Al-Qaysi, N., Salloum, S.A. (2021). Blended Learning Acceptance: A Systematic Review of Information Systems Models. Technology, Knowledge and Learning, https://doi.org/10.1007/s10758-021-09519-0

Al-Rahmi, W. M., Alias, N., Othman, M. S., Marin, V. I., \& Tur, G. (2018). A model of factors affecting learning performance through the use of social media in Malaysian higher education. Computers and Education, 121, 59-72.

Althunibat, A. (2015). Determining the factors influencing students' intention to use m-learning in Jordan higher education. Computers in Human Behavior, 52, 65-71.

Anshari, M., Almunawar, M. N., Shahrill, M., Wicaksono, D. K., \& Huda, M. (2017). Smartphones usage in the classrooms: Learning aid or interference?. Education and Information Technologies, 22(6), 3063-3079.

Araújo, F. J.,D.O., de Lima, L. S. A., Cidade, P. I. M., Nobre, C. B. \& Neto, M. L. R. (2020), "Impact of Sars-Cov-2 And its reverberation in global higher education and mental health”, Psychiatry Research, In Press. https://doi.org/10.1016/j.psychres.2020.112977

Bao, W. (2020), "COVID-19 and online teaching in higher education: A case study of Peking University”, Human Behavior and Emerging Technologies, 2(2), 113-115.

Baturay, M. H., Gökçearslan, Ş., \& Ke, F. (2017). The relationship among pre-service teachers' computer competence, attitude towards computer-assisted education, and intention of technology acceptance. International Journal of Technology Enhanced Learning, 9(1), 1-13.

Bergdahl, N., \& Nouri, J. (2020). Covid-19 and crisis-prompted distance education in Sweden. Technology, Knowledge and Learning, 1-17.

https://link.springer.com/article/10.1007/s10758-020-09470-6

Billinghurst, M., \& Duenser, A. (2012). Augmented reality in the classroom. Computer, 45(7), 56-63.

Boelens, R., Voet, M., \& De Wever, B. (2018). The design of blended learning in response to student diversity in higher education: Instructors' views and use of differentiated instruction in blended learning. Computers and Education, 120, 197-212.

Bolumole, M. (2020): Student life in the age of COVID-19, Higher Education Research and Development, DOI: 10.1080/07294360.2020.1825345

Briz-Ponce, L., Pereira, A., Carvalho, L., Juanes-Méndez, J. A., \& García-Peñalvo, F. J. (2017). Learning with mobile technologies-Students' behavior. Computers in Human Behavior, 72, 612620.

Butler, A., Camilleri, M. A., Creed, A., \& Zutshi, A. (2021). The use of mobile learning technologies for corporate training and development: A contextual framework. In Strategic corporate communication in the digital age. Emerald Publishing Limited, Bingley, UK. 
Camilleri, M. A., \& Camilleri, A. C. (2017). Digital learning resources and ubiquitous technologies in education. Technology, Knowledge and Learning, 22(1), 65-82.

Camilleri, M. A., \& Camilleri, A. C. (2019). The students' readiness to engage with mobile learning apps. Interactive Technology and Smart Education.17(1), 28-38.

Camilleri, M. A., \& Camilleri, A. C. (2020). The students' acceptance and use of their university's virtual learning environment. In Proceedings of the 2020 11th International Conferencing on E-Education, E-Business, E-Management, and E-Learning (pp. 48-53), Osaka, Japan. https://doi.org/10.1145/3377571.3377574

Camilleri, M. A. (2021a). Evaluating service quality and performance of higher education institutions: A systematic review and a post COVID-19 outlook. International Journal of Quality and Service Sciences. DOI: 10.1108/IJQSS-03-2020-0034

https://papers.ssrn.com/sol3/papers.cfm?abstract_id=3792091

Camilleri, M. A. (2021b). Using the balanced scorecard as a performance management tool in higher education. Management in Education, 35(1), 10-21.

Chattaraman, V., Kwon, W. S., Gilbert, J. E., \& Ross, K. (2019). Should AI-Based, conversational digital assistants employ social-or task-oriented interaction style? A taskcompetency and reciprocity perspective for older adults. Computers in Human Behavior, 90, 315-330.

Chen, Q., Chen, H. M., \& Kazman, R. (2007). Investigating antecedents of technology acceptance of initial eCRM users beyond generation $\mathrm{X}$ and the role of self-construal. Electronic Commerce Research, 7(3-4), 315-339.

Chen, Y., Wang, Y., Kinshuk, C. \& Chen, N. S. (2014). Is FLIP enough? Or should we use the FLIPPED model instead?. Computers and Education, 79, 16-27.

Cheng, M., \& Yuen, A. H. K. (2018). Student continuance of learning management system use: A longitudinal exploration. Computers and Education, 120, 241-253.

Cheon, J., Lee, S., Crooks, S. M., \& Song, J. (2012). An investigation of mobile learning readiness in higher education based on the theory of planned behavior. Computers and Education, 59(3), 1054-1064.

Cochrane, T. D. (2014). Critical success factors for transforming pedagogy with mobile W eb 2.0. British Journal of Educational Technology, 45(1), 65-82.

Crompton, H., \& Burke, D. (2018). The use of mobile learning in higher education: A systematic review. Computers and Education, 123, 53-64.

Cruz-Benito, J., Therón, R., García-Peñalvo, F. J., \& Lucas, E. P. (2015). Discovering usage behaviors and engagement in an Educational Virtual World. Computers in Human Behavior, 47, $18-25$.

Dabbagh, N., \& Kitsantas, A. (2012). Personal Learning Environments, social media, and selfregulated learning: A natural formula for connecting formal and informal learning. The Internet and Higher Education, 15(1), 3-8. 
Dalgarno, B., \& Lee, M. J. (2010). What are the learning affordances of 3-D virtual environments?. British Journal of Educational Technology, 41(1), 10-32.

Davis, F. D. (1989). Perceived usefulness, perceived ease of use, and user acceptance of information technology. MIS Quarterly, 13,(3), 319-340.

Dečman, M. (2015). Modeling the acceptance of e-learning in mandatory environments of higher education: The influence of previous education and gender. Computers in Human Behavior, 49, 272-281.

Di Mitri, D., Schneider, J., Specht, M., \& Drachsler, H. (2018). From signals to knowledge: A conceptual model for multimodal learning analytics. Journal of Computer Assisted Learning, 34(4), 338-349.

Dumpit, D. Z., \& Fernandez, C. J. (2017). Analysis of the use of social media in Higher Education Institutions (HEIs) using the Technology Acceptance Model. International Journal of Educational Technology in Higher Education, 14(1), 1-16.

Fiore, A. M., \& Jin, H. J. (2003). Influence of image interactivity on approach responses towards an online retailer. Internet Research, 13(1), 38-48.

Fitter, N. T., Raghunath, N., Cha, E., Sánchez, C. A., Takayama, L., \& Matarić, M. J. (2020). Are We There Yet? Comparing Remote Learning Technologies in the University Classroom. IEEE Robotics and Automation Letters, 5(2), 2706-2713.

Fornell, C., \& Larcker, D. F. (1981). Structural equation models with unobservable variables and measurement error: Algebra and statistics. Journal of Marketing Research, 18(3), 382-388.

Fowler, C. (2015). Virtual reality and learning: Where is the pedagogy?. British Journal of Educational Technology, 46(2), 412-422.

Fridin, M. (2014). Storytelling by a kindergarten social assistive robot: A tool for constructive learning in preschool education. Computers and Education, 70, 53-64.

Furió, D., Juan, M. C., Seguí, I., \& Vivó, R. (2015). Mobile learning vs. traditional classroom lessons: a comparative study. Journal of Computer Assisted Learning, 31(3), 189-201.

Gangwar, H., Date, H., \& Ramaswamy, R. (2015). Understanding determinants of cloud computing adoption using an integrated TAM-TOE model. Journal of Enterprise Information Management, 28(1), 107-130.

Gikandi, J. W., Morrow, D., \& Davis, N. E. (2011). Online formative assessment in higher education: A review of the literature. Computers and Education, 57(4), 2333-2351.

Gómez-Aguilar, D. A., Hernández-García, Á., García-Peñalvo, F. J., \& Therón, R. (2015). Tap into visual analysis of customization of grouping of activities in eLearning. Computers in Human Behavior, 47, 60-67.

Gonzalez, T., de la Rubia, M. A., Hincz, K. P., Comas-Lopez, M., Subirats, L., Fort, S., \& Sacha, G. M. (2020). Influence of COVID-19 confinement on students' performance in higher 
education. PloS one, 15(10),

https://journals.plos.org/plosone/article?id=10.1371/journal.pone.0239490

Hair Jr, J. F., Howard, M. C., \& Nitzl, C. (2020). Assessing measurement model quality in PLSSEM using confirmatory composite analysis. Journal of Business Research, 109, 101-110.

Hartshorne, R., \& Ajjan, H. (2009). Examining student decisions to adopt Web 2.0 technologies: theory and empirical tests. Journal of Computing in Higher Education, 21(3), 183.

Heilesen, S. B. (2010). What is the academic efficacy of podcasting?. Computers and Education, 55(3), 1063-1068.

Henseler, J., Ringle, C. M., \& Sarstedt, M. (2015). A new criterion for assessing discriminant validity in variance-based structural equation modeling. Journal of the Academy of Marketing Science, 43(1), 115-135.

Hoi, V. N. (2020). Understanding higher education learners' acceptance and use of mobile devices for language learning: A Rasch-based path modeling approach. Computers and Education, 146, https://doi.org/10.1016/j.compedu.2019.103761

Howley, I. (2020). Adapting guided inquiry learning worksheets for emergency remote learning. Information and Learning Sciences, 121(7/8), 549-557.

Hung, S. T. A. (2016). Enhancing feedback provision through multimodal video technology. Computers and Education, 98, 90-101.

Ifenthaler, D. (2012). Determining the effectiveness of prompts for self-regulated learning in problem-solving scenarios. Journal of Educational Technology \& Society, 15(1), 38-52.

Ifenthaler, D., \& Schweinbenz, V. (2013). The acceptance of Tablet-PCs in classroom instruction: The teachers' perspectives. Computers in Human Behavior, 29(3), 525-534.

Jeno, L. M., Grytnes, J. A., \& Vandvik, V. (2017). The effect of a mobile-application tool on biology students' motivation and achievement in species identification: A Self-Determination Theory perspective. Computers and Education, 107, 1-12.

Johnson, N., Veletsianos, G., \& Seaman, J. (2020). US Faculty and Administrators' Experiences and Approaches in the Early Weeks of the COVID-19 Pandemic. Online Learning, 24(2), 6-21.

Kurucay, M., \& Inan, F. A. (2017). Examining the effects of learner-learner interactions on satisfaction and learning in an online undergraduate course. Computers and Education, 115, 2037.

Khalifa, M., \& Kwok, R. C. W. (1999). Remote learning technologies: effectiveness of hypertext and GSS. Decision Support Systems, 26(3), 195-207.

Klašnja-Milićević, A., Vesin, B., Ivanović, M., \& Budimac, Z. (2011). E-Learning personalization based on hybrid recommendation strategy and learning style identification. Computers and Education, 56(3), 885-899. 
Lambić, D. (2016). Correlation between Facebook use for educational purposes and academic performance of students. Computers in Human Behavior, 61, 313-320.

Lambropoulos, N., Faulkner, X., \& Culwin, F. (2012). Supporting social awareness in collaborative e-learning. British Journal of Educational Technology, 43(2), 295-306.

Lee, Y. H., Hsieh, Y. C., \& Hsu, C. N. (2011). Adding innovation diffusion theory to the technology acceptance model: Supporting employees' intentions to use e-learning systems. Journal of Educational Technology and Society, 14(4), 124-137.

Lee, Y., \& Lee, J. (2014). Enhancing pre-service teachers' self-efficacy beliefs for technology integration through lesson planning practice. Computers and Education, 73, 121-128.

Lin, S., Zimmer, J. C., \& Lee, V. (2013). Podcasting acceptance on campus: The differing perspectives of teachers and students. Computers and Education, 68, 416-428.

Liu, Y. (2003). Developing a scale to measure the interactivity of websites. Journal of Advertising Research, 43(2), 207-216.

Liu, I. F., Chen, M. C., Sun, Y. S., Wible, D., \& Kuo, C. H. (2010). Extending the TAM model to explore the factors that affect Intention to Use an Online Learning Community. Computers and Education, 54(2), 600-610.

Liyanagunawardena, T. R., Adams, A. A., \& Williams, S. A. (2013). MOOCs: A systematic study of the published literature 2008-2012. International Review of Research in Open and Distributed Learning, 14(3), 202-227.

McMillan, S. J., \& Hwang, J. S. (2002). Measures of perceived interactivity: An exploration of the role of direction of communication, user control, and time in shaping perceptions of interactivity. Journal of Advertising, 31(3), 29-42.

McStay, A. (2020). Emotional AI and EdTech: serving the public good?. Learning, Media and Technology, 45(3), 270-283.

MacKenzie, S. B., \& Podsakoff, P. M. (2012). Common method bias in marketing: Causes, mechanisms, and procedural remedies. Journal of Retailing, 88(4), 542-555.

Makransky, G., Terkildsen, T. S., \& Mayer, R. E. (2019). Adding immersive virtual reality to a science lab simulation causes more presence but less learning. Learning and Instruction, 60, 225-236.

Merhi, M. I. (2015). Factors influencing higher education students to adopt podcast: An empirical study. Computers and Education, 83, 32-43.

Moore, J. L., Dickson-Deane, C., \& Galyen, K. (2011). e-Learning, online learning, and distance learning environments: Are they the same?. The Internet and Higher Education, 14(2), 129-135.

Moss, N. D., O'Connor, E. L., \& White, K. M. (2010). Psychosocial predictors of the use of enhanced podcasting in student learning. Computers in Human Behavior, 26(3), 302-309. 
Motiwalla, L. F. (2007). Mobile learning: A framework and evaluation. Computers and Education, 49(3), 581-596.

Ng, W. (2012). Can we teach digital natives digital literacy?. Computers and Education, 59(3), 1065-1078.

Ngai, E. W., Poon, J. K. L., \& Chan, Y. H. (2007). Empirical examination of the adoption of WebCT using TAM. Computers and Education, 48(2), 250-267.

Nistor, N. (2013). Stability of attitudes and participation in online university courses: Gender and location effects. Computers and Education, 68, 284-292.

Ocak, M. A. (2011). Why are faculty members not teaching blended courses? Insights from faculty members. Computers and Education, 56(3), 689-699.

Ozkan, S. \& Koseler, R. (2009), "Multi-dimensional students' evaluation of e-learning systems in the higher education context: An empirical investigation", Computers and Education, Vol. 53, No. 4, pp. 1285-1296.

Park, S. Y., Nam, M. W., \& Cha, S. B. (2012). University students' behavioral intention to use mobile learning: Evaluating the technology acceptance model. British Journal of Educational Technology, 43(4), 592-605.

Park, J. Y. (2015). Student interactivity and teacher participation: An application of legitimate peripheral participation in higher education online learning environments. Technology, Pedagogy and Education, 24(3), 389-406.

Payne, K., Keith, M. J., Schuetzler, R. M., \& Giboney, J. S. (2017). Examining the learning effects of live streaming video game instruction over Twitch. Computers in Human Behavior, 77, 95-109.

Porter, W. W., Graham, C. R., Spring, K. A., \& Welch, K. R. (2014). Blended learning in higher education: Institutional adoption and implementation. Computers and Education, 75, 185-195.

Rahiem, M. D. (2020). The emergency remote learning experience of university students in indonesia amidst the COVID-19 crisis. International Journal of Learning, Teaching and Educational Research, 19(6), 1-26.

Rakes, C. R., Ronau, R. N., Bush, S. B., Driskell, S. O., Niess, M. L., \& Pugalee, D. K. (2020). Mathematics achievement and orientation: A systematic review and meta-analysis of education technology. Educational Research Review, 31, https://www-sciencedirectcom.ejournals.um.edu.mt/science/article/pii/S1747938X19301800?via\%3Dihub

Rana, N. P., Slade, E., Kitching, S., \& Dwivedi, Y. K. (2019). The IT way of loafing in class: Extending the theory of planned behavior (TPB) to understand students' cyberslacking intentions. Computers in Human Behavior, 101, 114-123.

Rienties, B., \& Toetenel, L. (2016). The impact of learning design on student behaviour, satisfaction and performance: A cross-institutional comparison across 151 modules. Computers in Human Behavior, 60, 333-341. 
Ringle, C. M., Wende, S., \&Becker, J. M. (2014). SmartPLS 3. Hamburg: SmartPLS. Academy of Management Review, 9, 419-445.

Sablić, M., Mirosavljević, A., \& Škugor, A. (2020). Video-based learning (VBL)—past, present and future: An overview of the research published from 2008 to 2019. Technology, Knowledge and Learning, 1-17. https://link.springer.com/article/10.1007/s10758-020-09455-5

Sánchez, R. A., \& Hueros, A. D. (2010). Motivational factors that influence the acceptance of Moodle using TAM. Computers in Human Behavior, 26(6), 1632-1640.

Sánchez-Franco, M. J., Martínez-López, F. J., \& Martín-Velicia, F. A. (2009). Exploring the impact of individualism and uncertainty avoidance in Web-based electronic learning: An empirical analysis in European higher education. Computers and Education, 52(3), 588-598.

Sánchez-Franco, M. J. (2010). WebCT-The quasimoderating effect of perceived affective quality on an extending Technology Acceptance Model. Computers and Education, 54(1), 37-46.

Sánchez-Prieto, J. C., Olmos-Migueláñez, S., \& García-Peñalvo, F. J. (2017). MLearning and pre-service teachers: An assessment of the behavioral intention using an expanded TAM model. Computers in Human Behavior, 72, 644-654.

Schoonenboom, J. (2014). Using an adapted, task-level technology acceptance model to explain why instructors in higher education intend to use some learning management system tools more than others. Computers and Education, 71, 247-256.

Selwyn, N. (2010). Looking beyond learning: Notes towards the critical study of educational technology. Journal of Computer Assisted Learning, 26(1), 65-73.

Shih, H. P. (2008). Using a cognition-motivation-control view to assess the adoption intention for Web-based learning. Computers and Education, 50(1), 327-337.

Soflano, M., Connolly, T. M., \& Hainey, T. (2015). An application of adaptive games-based learning based on learning style to teach SQL. Computers and Education, 86, 192-211.

Sun, P. C., Tsai, R. J., Finger, G., Chen, Y. Y., \& Yeh, D. (2008). What drives a successful eLearning? An empirical investigation of the critical factors influencing learner satisfaction. Computers and Education, 50(4), 1183-1202.

Sung, Y. T., Chang, K. E., \& Yang, J. M. (2015). How effective are mobile devices for language learning? A meta-analysis. Educational Research Review, 16, 68-84

Sung, Y. T., Chang, K. E., \& Liu, T. C. (2016). The effects of integrating mobile devices with teaching and learning on students' learning performance: A meta-analysis and research synthesis. Computers and Education, 94, 252-275.

Tam, M. (2000). Constructivism, instructional design, and technology: Implications for transforming distance learning. Journal of Educational Technology and Society, 3(2), 50-60.

Tao, Y. H., Cheng, C. J., \& Sun, S. Y. (2009). What influences college students to continue using business simulation games? The Taiwan experience. Computers and Education, 53(3), 929-939. 
Teo, T. (2009). Modelling technology acceptance in education: A study of pre-service teachers. Computers and Education, 52(2), 302-312.

Teo, T., \& Zhou, M. (2014). Explaining the intention to use technology among university students: a structural equation modeling approach. Journal of Computing in Higher education, 26(2), 124-142.

Thai, N. T. T., De Wever, B., \& Valcke, M. (2017). The impact of a flipped classroom design on learning performance in higher education: Looking for the best "blend" of lectures and guiding questions with feedback. Computers and Education, 107, 113-126.

Thorson, K. S., \& Rodgers, S. (2006). Relationships between blogs as eWOM and interactivity, perceived interactivity, and parasocial interaction. Journal of Interactive Advertising, 6(2), 5-44.

Valk, J. H., Rashid, A. T., \& Elder, L. (2010). Using mobile phones to improve educational outcomes: An analysis of evidence from Asia. International Review of Research in Open and Distributed Learning, 11(1), 117-140.

Vanderhoven, E., Raes, A., Montrieux, H., Rotsaert, T., \& Schellens, T. (2015). What if pupils can assess their peers anonymously? A quasi-experimental study. Computers and Education, 81, 123-132.

Van Raaij, E. M., \& Schepers, J. J. (2008). The acceptance and use of a virtual learning environment in China. Computers and Education, 50(3), 838-852.

Venkatesh, V., Morris, M. G., Davis, G. B., \& Davis, F. D. (2003). User acceptance of information technology: Toward a unified view. MIS Quarterly, 27(3), 425-478.

Venkatesh, V., Thong, J. Y., \& Xu, X. (2012). Consumer acceptance and use of information technology: extending the unified theory of acceptance and use of technology. MIS Quarterly, 157-178.

Viberg, O., \& Grönlund, A. (2013). Cross-cultural analysis of users' attitudes toward the use of mobile devices in second and foreign language learning in higher education: A case from Sweden and China. Computers and Education, 69, 169-180.

Wang, Q., Woo, H. L., \& Zhao, J. (2009). Investigating critical thinking and knowledge construction in an interactive learning environment. Interactive Learning Environments, 17(1), 95-104.

Wang, Q. (2009). Design and evaluation of a collaborative learning environment. Computers and Education, 53(4), 1138-1146.

Wang, Y. S., Wu, M. C., \& Wang, H. Y. (2009). Investigating the determinants and age and gender differences in the acceptance of mobile learning. British Journal of Educational Technology, 40(1), 92-118.

Wu, G. (2005). The mediating role of perceived interactivity in the effect of actual interactivity on attitude toward the website. Journal of Interactive Advertising, 5(2), 29-39. 
Wu, H. K., Lee, S. W. Y., Chang, H. Y., \& Liang, J. C. (2013). Current status, opportunities and challenges of augmented reality in education. Computers and Education, 62, 41-49. 